\title{
A. 1189
}

\section{Calculated Irradiation Response of Materials Using a Fusion-Reactor First-Wall Neutron Spectrum}

\author{
T. A. Gabriel \\ B. L. Bishop \\ F. W. Wiffen
}

\section{OAK RIDGE NATIONAL LABORATORY}




\section{DISCLAIMER}

This report was prepared as an account of work sponsored by an agency of the United States Government. Neither the United States Government nor any agency Thereof, nor any of their employees, makes any warranty, express or implied, or assumes any legal liability or responsibility for the accuracy, completeness, or usefulness of any information, apparatus, product, or process disclosed, or represents that its use would not infringe privately owned rights. Reference herein to any specific commercial product, process, or service by trade name, trademark, manufacturer, or otherwise does not necessarily constitute or imply its endorsement, recommendation, or favoring by the United States Government or any agency thereof. The views and opinions of authors expressed herein do not necessarily state or reflect those of the United States Government or any agency thereof. 


\section{DISCLAIMER}

Portions of this document may be illegible in electronic image products. Images are produced from the best available original document. 


\section{Printed in the United States of America. Available from National Technical Information Service \\ U.S. Department of Commerce 5285 Port Royal Road, Springfield, Virginia 22161 \\ Price: Printed Copy $\$ 3.50$; Microfiche $\$ 3.00$}

This report was prepared as an account of work sponsored by the United States Government. Neither the United States nor the Energy Research and Development Administration/United States Nuclear Regulatory Commission, nor any of their employees, nor any of their contractors, subcontractors, or their employees, makes any warranty, express or implied, or assumes any legal liability or responsibility for the accuracy, completeness or usefulness of any information, apparatus, product or process disclosed, or represents that its use would not infringe privately owned rights. 
Contract No. W-7405-eng-26

METALS AND CERAMICS DIVISION

CALCULATED IRRADIATION RESPONSE OF MATERIALS USING

A FUSION-REACTOR FIRST-WALL NEUTRON SPECTRUM

T. A. Gabriel, B. L. Bishop, and F. W. Wiffen

Date Published - June 1977

To be published in Nuclear Technology

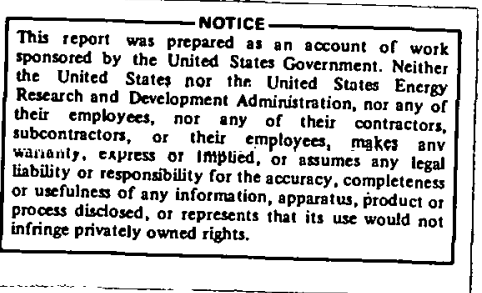

This report was prepared as an account of work the United Suted States Government. Neither Rescarch and Development Administration, nos any of wiability or express of iniplied, of assumes any legal

OAK RIDGE NATIONAL LABORATORY

Oak Ridge, Tennessee 37830

operated by

UNION CARBIDE CORPORATION

for the

ENERGY RESEARCH AND DEVELOPMENT ADMINISTRATION 


\section{THIS PAGE}

\section{WAS INTENTIONALLY \\ LEFT BLANK}


TABLE OF CONTENTS

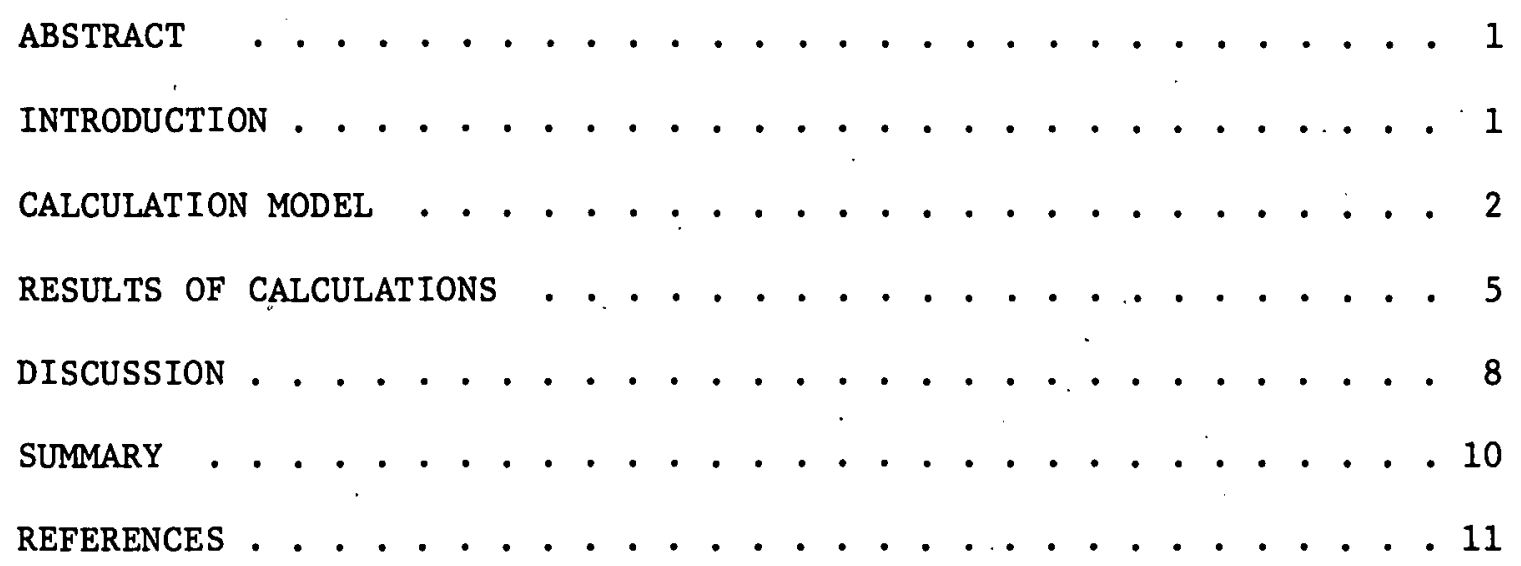

a 
CALCULATED IRRADIATION RESPONSE OF MATERIALS USING A FUSION-REACTOR FIRST-WALL NEUTRON SPECTRUM

T. A. Gabriel, B. L. Bishop, and F. W. Wiffen

ABSTRACT

This paper presents the calculated irradiation response in displacements per atom and gas production values of a number of elements and metal alloys in a fusion reactor firstwall neutron spectrum. The gas production rates for new alloy compositions can by synthesized from these results, and all comparisons are thus kept on a consistent basis. The sensitivity to the nuclear data base used and to the exact neutron spectrum is found to be greatest in the helium production rates. This helium production value in some alloys may also be sensitive to composition. In type 316 stainless steel variations of $\pm 9 \%$ are possible for compositions within the specification range.

\section{INTRODUCTION}

Predictions of the property changes that will result from metallic component service in a previously untested neutron spectrum are made by interpolation or extrapolation of the available understanding of irradiation effects. The best available basis for comparing neutron irradiation effects for exposures in different spectra is in terms of the calculated materials response, given in terms of displacements per atom (dpa), helium from $\alpha$-producing transmutations, and hydrogen from $(n, p)$ and other hydrogen isutope produclion rélicliuns.

The existing neutronics calculations available for fusion reactor spectra have been performed mainly for the materials used in conceptual

*Neutron Physics Divsion, ORNL, Uak Ridge, 'TN 37830.

**Computer Science Division, ORNL, Oak Ridge, TN 37830

tMetals and Ceramics Division, ORNL, Oak Ridge, TN 37830. 
designs. Results from different designs are not directly comparable owing to different approaches used in performing the calculations. One set of calculations is available ${ }^{1}$ comparing the response of several alloys of potential interest in a single fusion reactor spectrum. However, the results are not presented in a form to allow evaluation of the effect of alloy modification, and they are not based on the latest available neutron cross-section data.

This paper presents a self-consistent set of calculations of the neutronic response of a number of elements and alloys to a projected fusion reactor first wall neutron spectrum.

GALCIIT.ATTON MONFT.

The materials chosen for analysis include several alloys that are of potential use as structural materials in fusion reactors, namely type 316 stainless steel (taken to be of atomic composition $\mathrm{Fe}-19.4 \% \mathrm{Cr}-12.4 \%$ $\mathrm{Ni}-1.4 \% \mathrm{Mo}$ ), Nimonic PE-16 (taken as $\mathrm{Ni}-35.3 \% \mathrm{Fe}-18.1 \% \mathrm{Cr}-2.0 \% \mathrm{Mo}$ ), $\mathrm{V}-20 \% \mathrm{Ti}$, aluminum, n1oblum, and mulybdenum. Also included arc the elemental constituents of these alloys and other elements that are either common impurities or common alloy constituents.

All calculations have been performed for a single neutron spectrum. The spectrum used is the first wall spectrum calculated by santoro er al. ${ }^{2}$ for the stainless steel - 1ithium - graphite blanket shown schematically in one dimension in Fig. 1. The major difference between this blanket and most blankets previously analyzed is in the depth of the lithium zone; vị. $25 \mathrm{~cm}$ lithium zone in this blanket compared to $51 \mathrm{~cm}$ of 11thtum in the UWMAK-I design. ${ }^{3}$ The blanket indicated in Fig. 1 gives a calculated 
ORNL- DWG 75-10634R4

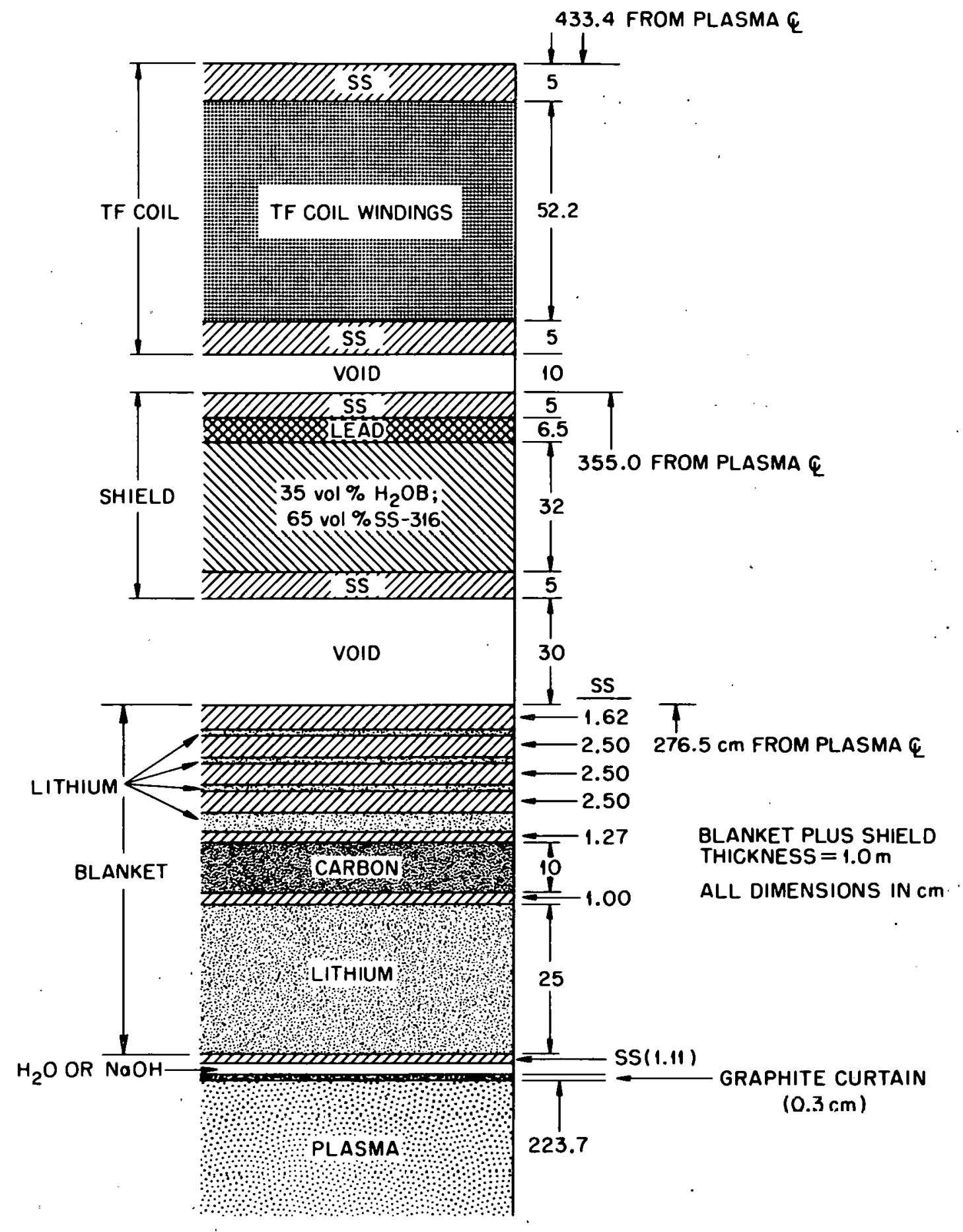

Fig. 1. Schematic One-Dimensional View of the Blanket and Shield Region of the Fusion Reactor Used for Analysis (From Reference 2). 
tritium breeding ratio of $1.15,{ }^{2}$ probably adequate for a fusion power reactor. The neutron spectrum in 20-group format is given in Table 1 .

Table 1. Neutron Energy Spectrum at the First Wall of the Fusion Reactor Shown in Fig. 1. This 20-group spectrum has been collapsed from the 100-group spectrum used in calculations. ${ }^{a}$

\begin{tabular}{|c|c|c|c|}
\hline $\begin{array}{l}\text { Energy Gruup } \\
\text { Number }\end{array}$ & $\begin{array}{c}\text { Lower Encrgy } \\
\text { of Group } \\
(M c V)\end{array}$ & $\begin{array}{l}\text { Fraction of } \\
\text { Nentrons in Group }\end{array}$ & $\begin{array}{l}\text { Fraction of Neutrons } \\
\text { with Energy Above } \\
\text { Group Lower Bound }\end{array}$ \\
\hline 1 & 14.92 & 0 & 0 \\
\hline 2 & 13.50 & 0.1893 & 0.1893 \\
\hline 3 & 10.00 & 0.0280 & 0.2173 \\
\hline 4 & 6.07 & 0.0368 & 0.2541 \\
\hline 5 & 3.01 & 0.0396 & 0.2937 \\
\hline 6 & 2.02 & 0.0365 & 0.3302 \\
\hline 7 & 1.50 & 0.0344 & 0.3646 \\
\hline 8 & 1.00 & 0.0521 & 0.4167 \\
\hline 9 & .672 & 0.0592 & 0.4759 \\
\hline 10 & .451 & 0.0629 & 0.5388 \\
\hline 11 & .247 & 0,0619 & 0.6007 \\
\hline 12 & .150 & 0.0542 & 0.6549 \\
\hline 13 & .111 & 0.0439 & 0.6988 \\
\hline 14 & .0865 & 0.0310 & 0.7298 \\
\hline 15 & .0525 & 0.0539 & 0.7837 \\
\hline 16 & .0318 & 0.0413 & 0.8250 \\
\hline 17 & .0117 & 0.0671 & 0.8921 \\
\hline 18 & .00123 & 0.0832 & 0.9753 \\
\hline 19 & .0001 & 0.0231 & 0.9984 \\
\hline 20 & $10^{-10}$ & 0.0016 & 1.0000 \\
\hline
\end{tabular}

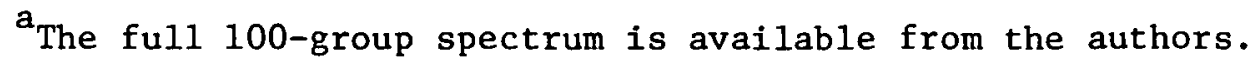


This spectrum has been collapsed from the full 100-group spectrum used in the calculations. The slight changes in the neutron spectrum that would result from the replacement of stainless steel by other structural materials have not been taken into account.

The methods used to calculate the irradiation response of elements of interest have been described in detail elsewhere. ${ }^{4}$ All elastic, inelastic, charged particle, and capture reactions which are considered in ENDF/B-IV have been included in this analysis. Nuclear data are taken from the ENDF/B-IV file, and displacement damage calculations follow the recommendations of the IAEA working group. ${ }^{5}$ For elements other than iron, effective displacement energies recommended by Doran and Graves ${ }^{6}$ were used.

\section{RESULTS OF CALCULATIONS}

The calculated data are given in Tables 2, 3, and 4. In Table 2 the dpa and gas-production rates are given for a neutron wall loading of

Table 2. DPA and Gas-Production Rates in Typical Candidate Alloys at the First Wall of a Fusion Reactora

\begin{tabular}{lcccc}
\hline Alloy & $\begin{array}{c}\text { Effective Displacement } \\
\text { Threshold Energy } \\
(\mathrm{eV})\end{array}$ & $\begin{array}{c}\text { Displacement } \\
\text { Damage } \\
(\mathrm{dpa} / \mathrm{sec})\end{array}$ & $\begin{array}{c}\text { Helium } \\
\text { (appm/sec) }\end{array}$ & $\begin{array}{c}\text { Hydrogen } \\
\text { (appm/ser. })\end{array}$ \\
\hline & & $\times 10^{-7}$ & $\times 10^{-7}$ & $\times 10^{-7}$ \\
$316 \mathrm{SS}$ & 40 & 3.64 & 45.6 & 169. \\
$\mathrm{PE}-16$ & 40 & 3.72 & 76.1 & 248. \\
$\mathrm{~A} 1$ & 25 & 4.63 & 101. & 94.5 \\
$\mathrm{~V}-20 \mathrm{Ti}$ & 40 & 3.65 & 18.7 & 72.5 \\
$\mathrm{Nb}$ & 60 & 2.31 & 9.18 & 33.3 \\
$\mathrm{Mo}$ & 60 & 2.38 & {$[15 .]^{\mathrm{b}}$} & {$[30 .]^{\mathrm{b}}$} \\
\hline
\end{tabular}

${ }^{a}$ Neutron wall loading $=1 \mathrm{MW} / \mathrm{m}^{2}$.

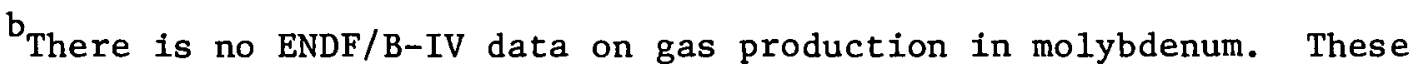
numbers are taken from Kulcinski, Doran, and Abdou, Reference (1), and are based on calculated cross-sections and on a slightly different firstwall neutron spectrum. 
$1 \mathrm{MW} / \mathrm{m}^{2}$. The accumulated damage responses for the alloys are given in Table 3 for a "lifetime" loading of $40 \mathrm{MW}-\mathrm{yr} / \mathrm{m}^{2}$. In addition, gasproduction and dpa calculations have been performed for some pure elements. These results, given in Table 4 , can be used to synthesize gas production In most alloys being considered for fusion reactor application. The effective displacement thresholds are also given. The dpa results for other thresholds can be obtained by multiplying by the ratio of the threshold value in Table 4 to the required threshold value.

Table 3. Total dpa and Gas Production in Typical Candidate First Wall Alloys for a Fusion Reactor Operation of $40 \mathrm{MW}$ year $/ \mathrm{m}^{2}$

\begin{tabular}{lcccc}
\hline A1loy & $\begin{array}{c}\text { Effective Displacement } \\
\text { Threshold Energy } \\
(\mathrm{eV})\end{array}$ & $\begin{array}{c}\text { Displacement } \\
\text { Damage } \\
\text { (dpa) }\end{array}$ & $\begin{array}{c}\text { Helium } \\
\text { (appm) }\end{array}$ & $\begin{array}{c}\text { Hydrogen } \\
\text { (appm) }\end{array}$ \\
\hline 316 SS & 40 & 460 & 5750 & 21,300 \\
PE-16 & 40 & 470 & 9590 & 31,200 \\
A1 & 25 & 580 & 12,700 & 11,900 \\
V-20 T1 & 40 & 460 & 2360 & 9,140 \\
N6 & 60 & 290 & 1160 & 4200 \\
Mo & 60 & 300 & $(1890)^{\text {a }}$ & $(3780)^{a}$ \\
\end{tabular}

There is no ENDF/B-IV data on gas production in molybdenum. These numbers are taken from Kulcinski, Doran, and Abdou, Reference (1), and are based on calculated cross-sections and on a slightly different firstwall neutron spectrum. 
Table 4. DPA and Gas-Production Rates in the Elemental Constituents of Candidate Alloys in a Fusion Reactor First Wall Neutron Spectrum ${ }^{a}$

\begin{tabular}{|c|c|c|c|c|c|}
\hline Element & $\begin{array}{c}\text { Effect } \\
\text { Displace } \\
\text { Thresh } \\
\text { Energy }\end{array}$ & $\begin{array}{l}\text { ve } \\
\text { ment } \\
\text { old } \\
\text { eV) }\end{array}$ & $\begin{array}{c}\text { Displacement } \\
\text { Damage } \\
(\mathrm{dpa} / \mathrm{sec})\end{array}$ & $\begin{array}{c}\text { Helium } \\
(\text { appm/sec) }\end{array}$ & $\begin{array}{c}\text { Hydrogen } \\
\text { (appm/sec) }\end{array}$ \\
\hline & - & & $\times 10^{-7}$ & $\times 10^{-7}$ & $\times 10^{-7}$ \\
\hline $\mathrm{Fe}$ & 40 & & 3.62 & 34.9 & 151. \\
\hline $\mathrm{Ni}$ & 40 & & 3.87 & 130 & 397. \\
\hline $\mathrm{Cr}$ & 40 & & 3.58 & 32.6 & 100 \\
\hline $\mathrm{Mn}$ & 40 & & 3.58 & 26.7 & 100 \\
\hline $\mathrm{V}$ & 40 & . & 3.63 & 15.0 & 78.2 \\
\hline $\mathrm{Nb}$ & 60 & & 2.31 & 9.18 & 33.3 \\
\hline Mo & 60 & & 2.38 & $\mathrm{~b}$ & $\mathrm{~b}$ \\
\hline $\mathrm{T} i$ & 30 & & 5.03 & 33.5 & 49.7 \\
\hline $\mathrm{Zr}$ & 50 & & 2.54 & 2.93 & 25.2 \\
\hline $\mathrm{A} 1$ & 25 & & 4.63 & 101. & 94.5 \\
\hline $\mathrm{Mg}$ & 40 & & 2.80 & 147. & 148. \\
\hline $\mathrm{Cu}$ & 30 & & 4.88 & 31.8 & 173 \\
\hline Co & 40 & . & 3.60 & 23.1 & 73.7 \\
\hline C & & & c & 604 & b \\
\hline $\mathrm{N}$ & & & c & 205 . & 144. \\
\hline 0 & & & c & 118 & 41.0 \\
\hline Si : & 25 & & 4.61 & 1.59 & 298 . \\
\hline $10_{B}$ & & & c & 8980. & 28.7 \\
\hline $1 l_{B}$ & & & $c$ & 23.6 & 12.5 \\
\hline${ }^{6} \mathrm{Li}$ & & & c & 3081 . & 3071 . \\
\hline${ }^{7} \mathrm{Li}$ & & & c & 360. & 367. \\
\hline
\end{tabular}

a Neutron wall loading $=1 \mathrm{MW} / \mathrm{m}^{2}$.

${ }^{b}$ No ENDF/B-IV data on gas production.

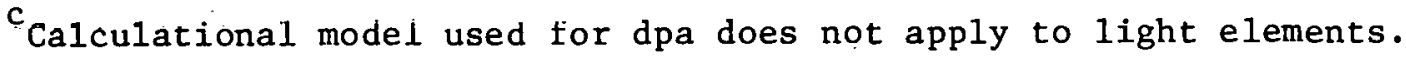




\section{DISCUSSION}

With the current interest in fusion reactor designs based on the "conventional" alloys of the $\mathrm{Fe}-\mathrm{Cr}-\mathrm{Ni}$ system, it is important to have an understanding of the difference in irradiation response between the many candidate alloys in this system. Tables 2 and 3 show that there is a significant difference in the gas production rates in type 316 stainless steel and Nimonic alloy PE-16, although displacement rates are nearly identical. Table 4 shows that the differences In guo production rntro between these two alloys are almost entirely caused by the differences in nickel content. This conclusion also applies to the other stainless steels, superalloys, and other conventional alloys that could be chosen from the $\mathrm{Fe}-\mathrm{Cr}-\mathrm{Ni}$ system. Changes in iron or chromium content or in any of the many minor alloying additives will have little influence on the gas production rate; that rate will be dominated by the nickel content. The helium production rate throughout the entire class of $\mathrm{Fe}=\mathrm{Cr}=\mathrm{Ni}$ alloys will range from the value for pure iron to the value for pure nickel. That is, the range of helium production in these alloys will be 110 to 410 appm per $M W-y r / m^{2}$ of fusion reactor operation.

It has been shown earlier ${ }^{4}$ that improvements in nuclear data in ENDF/B-IV compared to the earlier ENDF/B-III resulted in some changes in the calculated fusion reactor irradiation response. In the cases examined, the musl important changc was a decrease in the ralculated helium production rate in type 316 stainless steel, reflecting a decrease in the $(n, \alpha)$ cross section for iron.

The calculations in this paper were based on the first-wall neutron spectrum of a Tokamak designed to provide adequate tritium breeding without 
excessive tritium inventory. These boundary conditions give a narrower 1ithium zone and a softer neutron spectrum than in several earlier studies. The major effect on the materials response is again a decrease in the helium production rate in stainless steel. ${ }^{*}$ other changes produced by the spectrum change are much less important. This series of changes In the helium production rate in type 316 stainless steel is shown in Table 5. Hydrogen production rates from the same studies show both the small change in nuclear data for hydrogen production reactions and the relative insensitivity of hydrogen production to small changes in the first wall neutron spectrum.

A range of composition is always allowed in the specification of an alloy. The data in Table 4 have been used to evaluate the effect of such variation on the rate of helium production in a type 316 stainless steel first wall. Two specifications were used, the "standard" AISI specification for 316 and the more restrictive AEC-RDT specification. The results of this sensitivity analysis are shown in Table 6, where compositions within specifications were adjusted first to minimize and then to maximize the helium production. Average helium production for the AISI specification range was $47.4 \times 10^{-7} \mathrm{appm} / \mathrm{sec}$, with extremes for the composition range $\pm 9.0 \%$ of the average. Within the more closely controlled AEC-RDT specification, the average production rate was higher, $49.3 \times 10^{-7}$ appm/sec, with the rate extremes for the composition range only $\pm 2.4 \%$ of the average.

*Slight differences in the composition assumed for 316 stainless steel in the three cases treated in Table 5 have probably also affected the calculated helium production rates. 
Table 5. Gas Production in Type 316 Stainless Steel for Several Calculational Cases.

\begin{tabular}{|c|c|c|c|c|}
\hline \multirow[t]{2}{*}{$\begin{array}{c}\text { Nuclear Data } \\
\text { Base }\end{array}$} & \multirow[t]{2}{*}{$\begin{array}{l}\text { Neutron } \\
\text { Spectrum }\end{array}$} & \multirow[t]{2}{*}{ Reference } & $\begin{array}{l}\text { Helium } \\
\text { Production } \\
\text { Rate }\end{array}$ & $\begin{array}{l}\text { Hydrogen } \\
\text { Production } \\
\text { Rate }^{\mathrm{a}}\end{array}$ \\
\hline & & & $\mathrm{appm} / \mathrm{sec}$ & appm/sec \\
\hline & & & $\left(\times 10^{-7}\right)$ & $\left(\times 10^{-7}\right)$ \\
\hline ENDF/B-III & UWMAK-I & (1) & 64 & 170 \\
\hline $\mathrm{ENDF} / \mathrm{B}=\mathrm{IV}$ & Early EPR & (4) & 56 & 179 \\
\hline ENDE / B =IV & F.PR, $25 \mathrm{~cm} \mathrm{Li}$ & (b) & 45.6 & 169 \\
\hline
\end{tabular}

${ }^{\text {a }}$ Differences in the assumed composition of type 316 stainless steel could account for part of the calculated differences in the gas production rates.

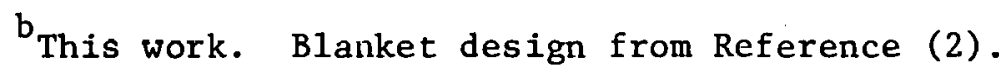

\section{SUMMARY}

This paper provides a set of self-consistent calculations of the irradiation response of candidate structural alloys to the neutron spectrum at the first-wall of a fusion reactor. Results are also included for the elements that are constituents of the common alloy systems. These results can be used to synthesize the response of alloys of interest that have not been Included explicitly, and thus make possible the comparison of any set of alloys on a consistent basis.

Comparison of results for stainless steel with previous calculations show that dpa and hydrogen productlun lales are relatively inocnultivy to differences in nuclear data between ENDF/B-III and ENDF/B-IV and to slight neutron spectrum changes between different Tokamak designs. Helium production in alloys based on the $\mathrm{Fe}-\mathrm{Cr}-\mathrm{Ni}$ system are sensitive to these changes and to changes in composition within the specification range for 
Table 6. Variation in Helium Production Rate in Type 316 Stainless Steel for Compositional Variations Within Specification Range.

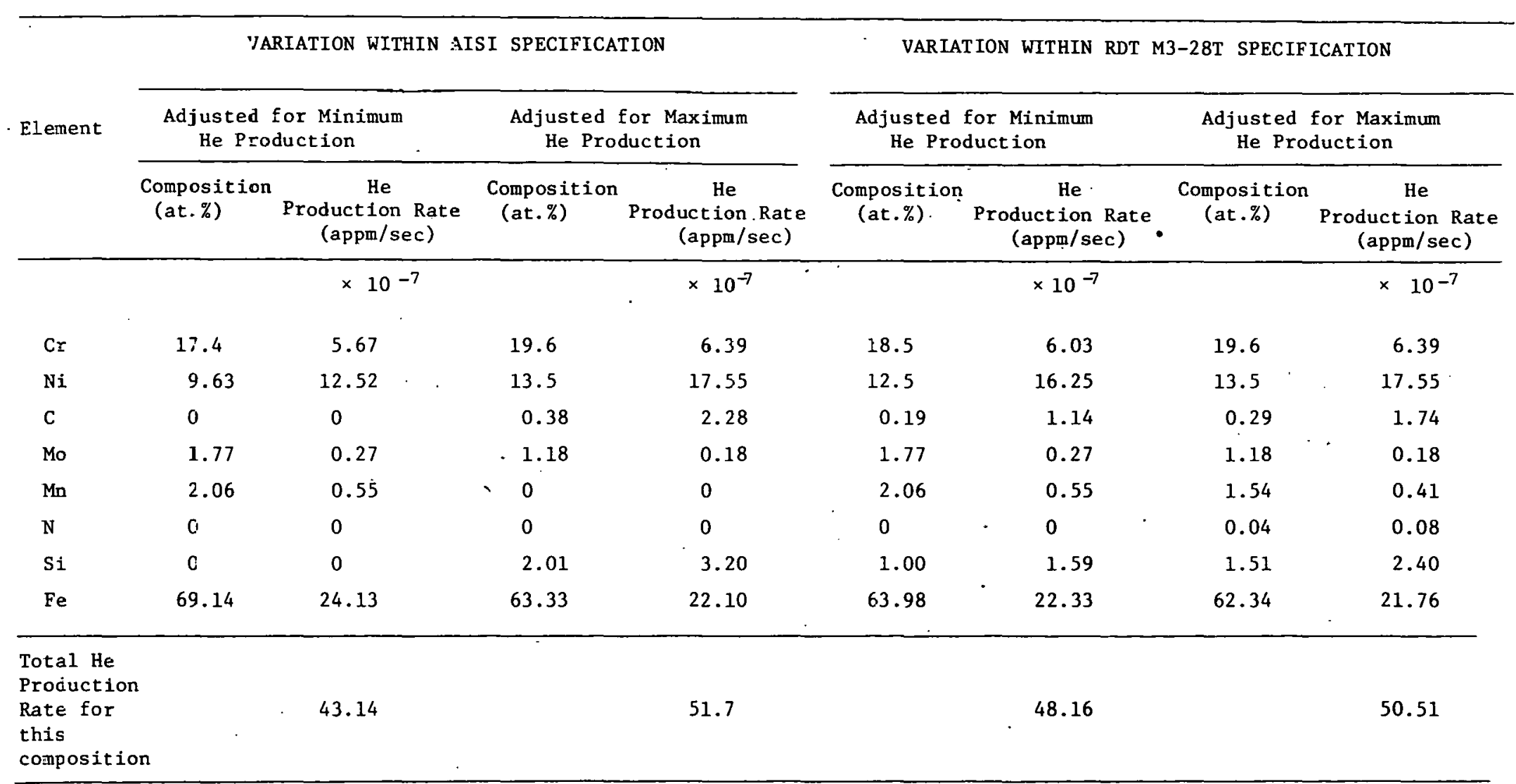


the given alloy. Coupled with the well-established effect of helium on the engineering properties of metals, this mandates careful attention to reactor design changes that change the neutron spectrum. The dominant effect of nickel content on the helium production also requires that the exact alloy composition (or at least the specific nickel content) be treated, rather than assuming similar behavior for all alloys of a single class.

\section{REFERENCES}

1. G. L. Kulcinski, D. G. Doran, and M. A. Abdou, "Comparison of Displacement and Gas Production Rates in Current Fission and Future Fusion Reactors," p. 329 in Properties of Reuctor Structural A.Zoys After Neutron or Particle Irradiation, ASTM STP 570, ASTM 1975.

2. R. T. Santoro, V. C. Baker, and J. M. Barnes, "Neutronics and Photonics Calculations for the Tokamak Experimental Power Reactor," ORNL/TM-5466 (in preparation).

3. B. Radger et al. UWMAK-I, A Wisconsin Toroidal Fusion Reactor Design, UWFDM-68, University of Wisconsin, November 1973.

4. T. A. Gabrie1, J. D. Amburgey, and N. M. Greene, "Radiation-Damage Calculations: Primary Knock-On Atom Spectra, Displacement Rates, and Gas-Production Rates," Nuol. Sci. Eng. 61., 21 (1976).

5. "Recommendations for Displacement Calculations for Reactor/Accelerator Studies in Austenitic Șteel," (Keport of IAEA Speclalists Meeting on Radiation Damage Units in Ferritic and Austenitic Steel.) Nucl. Eng. and Design, 33, 91 (1975).

6. D. G. Doran and N. J. Graves, "Neutron Displacement Damage Cross Sections for Structural Metals," p. 463 in Irruatiation Effeate in the Microstructure and Properties of Metals, ASTM STP 611, ASTM 1976. 


\section{INTERNAL DISTRIBUTION}

1-3. Central Research Library

4. ORNL - Y-12 Technical Library

5. Laboratory Records Department

6. Laboratory Records, ORNL RC

7. ORNL Patent Office

8. R. G. Alsmiller, Jr.

9. E. S. Bettis

10-15. B. L. Bishop

16. C. R. Brinkman

17. J. F. Clarke

18. R. J. Colchin

19. A. P. Fraas

20-25. T. A. Gabriel

26. M. L. Grossbeck

27-28. M. R. Hill

29. J. A. Horak

30. K. C. Liu

31. C. J. Long

32. P. J. Maziasz
33. H. E. McCoy, Jr.

34. C. J. McHargue

35. O. B. Morgan, Jr.

36. M. Roberts

37. M. T. Robinson

38. M. W. Rosentha1

39. R. T. Santoro

40. J. L. Scott

41. T. E. Shannon

42. D. Steiner

43. J. O. Stiegler

44. D. B. Trauger

45. N. A. Uckan

46. J. R. Weir, Jr.

47-61. F. W. Wiffen

62. M. K. Wilkinson

63. A. Zucker

64. R. W. Balluffi (consultant)

65. W. S. Hibbard (consultant)

EXTERNAL DISTRIBUTION

66-71. ARGONNE NAT IONAL LABORATORY, 9700 South Cass Avenue, Argonne, IL 60439
M. A. Abdou
R. R. Heinrich
J. B. Darby, Jr.
F. V. Nolfi, Jr.
S. D. Harkness
P. R. Okamoto

72. AMES LABORATORY, Iowa State University, Ames, Iowa 50010

M. S. Wechsler

73-75. BROOKHAVEN NATIONAL LABORATORY, Upton, NY 11973
A. N. Goland
J. Puwell
C. L. Snead, Jr.

76. ATOMICS INTERNATIONAL, P. O. Box 1608, Canoga Park, CA 91340

H. Farrar 
77. BATTELLE, PACIFIC NORTHWEST LABORATORY, P. O. Box 999, Richland WA 99352

J. L. Brimhall

78. UNIVERSITY OF CALIFORNIA, Santa Barbara, CA 93107

G. R. Odette

79. UNIVERSITY OF CALIFORNIA, LAWRENCE LIVERMORE LABORATORY

P. O. Box 808, Livermore, CA 94550 - R. R. Vandervoort

80. CULHAM LABORATORY, Abingdon, UK

R. Háncox

81. ELECTRIC POWER RESEARCH INSTITUTE, Palo Aito, CA 94304

W. C. Gough

82-85. LOS ALAMOS SCIENTIFIC LABORATORY, P. O. BOX 809,

Los Alamos, NM 87544

F. W. Clinard, Jr.

D. J. Dudziak

C. R. Emigh

D. M. Parkin

86-87. GENERAL ATOMIC COMPANY, San Diego, CA 92138

G. R. Hopkins

S. M. Rosenwasser

88-91. HANFORD ENGINEERING DEVELOPMENT LABORATORY, P. O. Box 1970, Richland, WA 99352
D. G. Doran
J. J. Huluies
E. R. Gilbert
H. H. Yoshikawa

92. INSTITUTE FÜR FESTKORPERFORSCBURG, der Kernforschungsanlagr, Jülich, D-5171, Postfoch 365, Germany

H. U11maier

33-94. MASSACHUGETTS INSTITUTE OF TEC.HNOIOGY, Cambridge, MA 02139

o. K. Harling

D. J. Rose

95. MAX-PLANK-INSTITUT FÜR PLASMAPHYSIK, D8046, Garching/Munchen, Germany

W. Dänner 
96-97. MCDONNEL-DOUGLAS ASTRONAUTICS COMPANY - EAST, P. O. Box 516, St. Louis, MO 63166

D. L. Kummer .

J. W. Davis

98. NAVAL RESEARCH LABORATORY, Code 6390, Washington, D. C. 20390

F. A. Smidt

99. PRINCETON PLASMA PHYSICS LABORATORY, P. O. BOX 451, Princeton, NJ 08540

Peter Bonanos

S. A. Cohen

100. OHIO STATE UNIVERSITY, Met. Engineering Dept., Columbus, Ohio 43200

P. G. Shewmon

101. SANDIA LABORATORIES, P. O. Box 5800, Albuquerque, NM 87115

S. T. Picraux

102. SANDIA LABORATORIES, Livermore, CA 94550

W. Bauer

103-105. WESTINGHOUSE ELECTRIC CORPORATION, Research and Development Center, Pittsburg, PA 15235

R. T. Begley

R. E. Gold

J. A. Spitznage1

106-109. THE UNIVERSITY OF WISCONSIN, Nuclear Engineering Department, Engineering Research Building, Room 433, Madison, WI 53706
R. W. Conn
P. Wilkes
G. L. Kulcinski
W. G. Wolfer

110-117. ERDA DIVISION OF MAGNETIC FUSION ENERGY, Washington, DC 20545
M. M. Cohen
T. C. Reuther, Jr.
E.N.C. Dalder
B. .. Twining
N. A. Davies
J. M. Williams
C. R. Finfgeld
K. M. Zwilsky

118. ERDA DIVISION OF PHYSICAL RESEARCH, Washington, DC 20545

L. C. Ianniello 
119-120. ERDA, P. O. Box E, Oak Ridge, TN 37830

Director, Reactor Division

Director, Research and Technical Support Division

121-310. ERDA TECHNICAL INFORMATION CENTER, Office of Technica1

Information $P$. 0. Box 62, Oak Ridge, TN 37830

For distribution as shown in TID-4500 Distribution Category, UC-20 (Controlled Thermonuclear Processes and Plasma Physics) 